\title{
TAXABLE INCOME DAN PERAN PEMODERASI SUMBANGAN REPRESENTASI (Penelitian Pada Perusahaan Manufaktur Sub Sektor Logam dan Lainnya Yang Terdaftar Pada Bursa Efek Indonesia Periode 2013-2017)
}

\author{
Abdu Rahman \\ Accounting Study Program, Faculty of Economy \\ Universitas Pancasila, Jakarta, Indonesia \\ abdujkt@gmail.com \\ Dr. Nurmala Ahmar, S.E., M.Si, Ak, CA \\ Universitas Pancasila, Jakarta, Indonesia \\ ahmarnurmala@gmail.com
}

\begin{abstract}
Abstrak
Terdapat beberapa akun yang termasuk dalam kategori Permanent Different dalam koreksi fiskal. Beberapa akun tersebut adalah Penghasilan Bunga, Penghasilan Berpajak Final, Sumbangan Representasi dan Beban Pajak yang merupakan salah satu penyebab perbedaan hasil perhitungan Taxabel Income antara pihak Perpajakan dan para Wajib Pajak untuk menentukan Taxabel Income bagi perusahaan wajib pajak. Tujuan penelitian adalah untuk mengetahui Determinasi dari penghasilan bunga dan penghasilan berpajak final terhadap Taxabel Income, sakaligus setelah dimoderasi oleh sumbangan representasi dan beban pajak terhadap Taxabel Income. Metode penelitian ini menggunakan pendekatan kuantitatif dan pengolahan data menggunakan software Warp-PLS. Penelitian ini menggunakan pengamatan pada perusahaan manufaktur untuk subsector logam dan sejenisnya yang terdaftar di Bursa Efek Indonesia Periode Tahun 2013-2017, yang merupakan file dokumentasi Direktorat Jendral Perpajakan Kementerian Keuangan Republik Indonesia. Hasil penelitian ini menunjukan adanya determinasi yang signifikan begitu juga hasil moderasi menunjukan hasil yang signifikan.
\end{abstract}

\section{Kata Kunci: Taxable Income, Sumbangan Representasi.}

\section{Pendahuluan}

Berbagai hasil penelitian terkait dengan permanent different dan Taxable Income menunjukkan hasil yang berbeda. Karenanya dalam penelitian ini penulis bermaksud untuk menganalisis kembali pengaruh koreksi fiscal, khususnya unsur-unsur permanent different terhadap Taxable Income. Penelitian ini menggunakan data panel (Gabungan data runtut waktu dan data silang) dengan populasi perusahaan yang bergerak di sektor manufakture yang terdaftar di Bursa Efek Indonesia periode 2013-2017. Pemilihan populasi ini dikarenakan bahwa pada umumnya perusahaan yang bergerak di bidang perbankan relatif memiliki banyak sektor yang terkait dengan materi dalam penelitian ini, khususnya pada biaya dan denda pajak serta unsur-unsur permanent different yang lain, disamping adanya keragaman yang rendah dalam berbagai pos akuntansi, yang diharapkan data yang diperoleh bisa memberikan dukungan yang signifikan dalam penelitian ini. Maka penelitian ini adalah bertujuan untuk Menganalisis Pengaruh Penghasilan Bunga Terhadap Taxable Income, Menganalisis Pengaruh Penghasilan Bepajak Final Terhadap Taxable Income, Menganalisis Pengaruh Penghasilan Bunga 
yang dimoderasi oleh Sumbangan Representasi Terhadap Taxable Income, Menganalisis Pengaruh Penghasilan Berpajak Final yang dimoderasi oleh Beban Pajak Terhadap Taxable Income. Penelitian ini diharapkan akan memberikan beberapa manfaat baik yang bersifat teoritis maupun manfaat yang bersifat praktis, yang diantaranya adalah secara teoritis sebagai bahan referensi bagi kegiatan penelitian lebih lanjut, khususnya untuk materi penelitian yang terkait dengan koreksi fiskal, sebagai bahan komparasi bagi kalangan akademisi karena terkait erat dengan mata kuliah bidang perpajakan, audit, dan akuntansi dan beberapa jenis mata kuliah terkait lainnya. Secara Praktis bisa sebagai suatu pertimbangan dalam perancangan strategi pengelolaan Profit Persistence, Profit Planning, Tax Planning dan Profit management dan strategi pengelolaan usaha lainnya, khususnya bagi para pelaku usaha atau para wajib pajak, terkait dengan adanya Permanent different yang merupakan pembentuk dari aset pajak tangguhan yang sangat berperan dalam manajemen laba, sebagai bahan masukan bagi pihak-pihak yang berkecimpung atau berprofesi dalam bidang perpajakan, karyawan, konsultan bidang perpajakan, dan pelaku usaha bidang jasa layanan perpajakan pada umumnya sehingga diharapkan akan bisa menjadi pertimbangan atau sekedar perbandingan didalam pelaksanaan kewajiban perpajakannya atau profesi dan bidang tugasnya dan kewenangannya masingmasing, sekedar bahan masukan bagi pemerintah atau otoritas perpajakan didalam merancang suatu peraturan atau ketentuan bidang perpajakan yang lebih jelas dan berkeadilan sehingga akan dapat lebih memudahkan bagi para wajib pajak di dalam melaksanakan kewajiban perpajakannya dan meminimalkan multi tafsir di dalam menyikapi ketentuan ataupun peraturan tersebut.

\section{Rumusan Masalah}

Berdasarkan pada latar belakang tujuan dan identifikasi masalah tersebut di atas, maka masalah dalam penelitian ini bisa dirumuskan apakah terdapat pengaruh penghasilan bunga terhadap taxable income, juga apakah terdapat pengaruh penghasilan berpajak final terhadap taxable income, juga apakah terdapat pengaruh penghasilan bunga yang dimoderasi oleh sumbangan representasi terhadap taxable income, dan apakah terdapat pengaruh penghasilan berpajak final yang dimoderasi oleh beban pajak terhadap taxable income.

\section{Literature Reviews}

\section{Pajak}

Menurut Undang Undang Nomor 16 Tahun 2009, tentang Ketentuan Umum dan Tata Cara Perpajakan, pajak merupakan suatu kegiatan dimana wajib orang pribadi atau badan berkontribusi secara wajib kepada negara yang sifatnya memaksa, undang-undang yang masih berlaku, serta tidak menerima imbalan secara langsung. Secara umum, pajak merupakan iuran yang wajib dibayar oleh rakyat pada negara, agar tercapainya kesejahteraan dan kemakmuran rakyat. Ilyas dan Burton (2007) menjelaskan, terdapat empat jenis fungsi pajak diantaranya fungsi budgetaird/fiskal, fungsi regulerend, fungsi demokrasi, fungsi distribusi. Dalam perpajakan sistem pemungutan pajak dibedakan menjadi 3 macam, yakni With holding system, Official assessment system, dan Self assessment system.

\section{Pajak Penghasilan}

Pajak penghasilan $(\mathrm{PPh})$ terjadi apabila subjek pajak orang pribadi ataupun badan menerima penghasilan dalam satu tahun pajak, maka diwajibkan atas diri mereka untuk dikenakan pajak. Pajak penghasilan memiliki dasar hukum yang tercantum pada Undang-Undang No. 7 tahun 1984 
mengenai Pajak Penghasilan (PPh) yang telah dirubah dengan Undang-Undang Nomor 36 Tahun 2008 (Mardiasmo, 2011). Suatu apapun yang berpotensi untuk mendapatkan penghasilan yang dijadikan sasaran dalam pengenaan pajak penghasilan maka termasuk sebagai subjek pajak penghasilan.

\section{Laporan Keuangan}

Salah satu bentuk informasi yang bisa diberikan oleh pihak manajemen kepada pihak pemegang saham sebagai sarana untuk penyampaian laporan kinerjanya adalah berupa laporan keuangan yang merupakan hasil akhir dari suatu proses pencatatan dan merupakan suatu ringkasan dari transaksi-transaksi keuangan yang terjadi dalam kurun waktu selama tahun buku atau suatu periode yang bersangkutan. Munawir (2010:5) menyatakan bahwa laporan keuangan pada umumnya terdiri dari neraca dan perhitungan laba rugi serta perubahan ekuitas. Neraca menggambarkan jumlah aset, kewajiban dan ekuitas dari suatu perusahaan pada peroide tertentu. Sedangkan laba rugi menunjukan hasilhasil dan beban perusahaan yang telah dicapai. Menurut Penyataan Standar Akuntansi Keuangan (PSAK) No.1 (Revisi 1 Januari 2015) Paragraf kesembilan, menyatakan bahwa Laporan keuangan adalah suatu penyajian terstruktur dari posisi keuangan dan kinerja keuangan suatu entitas. Sedangkan menurut Kasmir (2012:7), "Laporan keuangan adalah laporan yang menunjukkan kondisi keuangan perusahaan pada saat ini atau dalam suatu periode tertentu". Berdasarkan pengertian-pengertian di atas, dapat disimpulkan bahwa laporan keuangan adalah daftar ringkasan dari transaksitransaksi keuangan yang terjadi selama tahun buku yang dapat digunakan sebagai alat komunikasi dengan pihak-pihak yang berkepentingan serta untuk mempertanggungjawabkan tugas-tugas yang diberikan kepada pihak manajemen oleh para pemilik perusahaan. Laporan keuangan yang lengkap biasanya meliputi Laporan keuangan dibuat sebagai bagian dari proses pelaporan keuangan yang lengkap dan menyeluruh. Penyusunan laporan keuangan disiapkan mulai dari berbagai sumber data, yang terdiri dari berbagai faktur, kwitansi, bon, nota kredit, salinan faktur penjualan, salinan faktur pembelian, laporan bank dan bukti-bukti transaksi yang lainnya. Data yang asli merupakan dokumen yang penting, yang bukan saja digunakan untuk mengisi buku perkiraan, tetapi dapat juga dipakai untuk membuktikan keabsahan transaksi. Laporan keuangan diharapkan disajikan secara layak, jelas, lengkap dan informatif, yang mengungkapkan kenyataankenyataan ekonomi mengenai eksistensi dan kegiatan operasinal perusahaan dan menghindari laporan keuangan yang bersifat penyimpangan (bias), salah penafsiran dan ketidaktepatan.

\section{Permanent Difference}

Perbedaan yang timbul sebagai akibat perbedaan pengakuan penilaian elemenelemen laporan keuangan (aktiva, kewajiban, ekuitas, penghasilan, beban, untung, dan rugi) yang berlaku dalam disiplin akuntansi perpajakan (ketentuan/peraturan perpajakan) disatu pihak, dengan standar atau ketentuan yang berlaku dalam disiplin akuntansi keuangan dipihak yang lain yang bersifat tetap. Perbedaan Tetap mengakibatkan timbulnya koreksi fiskal terhadap laporan akuntansi atau laporan laba rugi komersial dalam penghitungan penghitungan laba kena pajak sebagai dasar penghitungan $\mathrm{PPh}$ terutang dan sebagai lampiran SPT Tahunan.

\section{Faktor-Faktor Penghambat Pengenaan Pajak}

Menurut KBBI hambatan sama dengan halangan atau rintangan, hambatan mempunyai pengertian penting dalam menjalankan tugas/pekerjaan. Tugas/pekerjaan tidak akan berjalan dengan baik jika terjadi suatu hambatan. 
Menurut Mardiasmo (2002) ada beberapa hambatan terhadap pengenaan pajak yang dibagi atas dua jenis, diantaranya: Perlawanan pasif yakni masyarakat tidak ingin melakukan pembayaran pajak, yang disebabkan karena sistem perpajakan yang mungkin susah dimengerti oleh masyarakat, dan kemampuan intelektual atau moral masyarakat yang masih kurang. Dan perlawanan aktif yakni masyaraakat melakukan sikap penghindaran pembayaran pajak yang ditujukan langsung pada fiskus, yaitu Tax Avoidance merupakan suatu usaha tanpa tidak melanggar Undang Undang untuk meringankan beban pajak, dan Tax Evasion merupakan suatu usaha yang melanggar undang-undang dengan tujuan untuk meringankan beban pajak seperti penggelapan pajak. Berdasarkan kajian teori di atas, maka dapat dirumuskan hipotesis sebagai berikut:

$\mathrm{H}_{1}$ : Pengaruh penghasilan bunga terhadap taxable income.

$\mathrm{H}_{2}$ : Pengaruh penghasilan berpajak final terhadap taxable income.

$\mathrm{H}_{3}$ : Pengaruh penghasilan bunga terhadap taxable income yang dimoderasi oleh sumbangan representasi

$\mathrm{H}_{4}$ : Pengaruh penghasilan berpajak final terhadap taxable income yang dimoderasi oleh beban pajak.

\section{METODE PENELITIAN}

Penelitian ini didisain dengan menggunakan jenis penelitian kuantitatif yang berupa penelitian deskriptif comparative terkait dengan fenomena Pernanent Differences yang merupakan unsur dari koreksi fiskal. Terdapat beberapa unsur yang membentuk Pernanent Differences pada laporan keuangan perusahaan ataupun wajib pajak pada umumnya, yang harus direkonsiliasi fiskal agar bisa disusun koreksi fiskal. Beberapa unsur yang terkandung dalam Pernanent Difference tersebut adalah Penghasilan Bunga, Penghasilan Berpajak
Final, Sumbangan Representasi, Denda pajak dan Biaya Lain-lain, serta unsurunsur pembentuk Permanent Difference lainnya. Berbagai variabel yang merupakan bagian dari Permanent Differences tersebut, beserta unsur Taxable Income adalah merupakan variabel yang secara ilmiah dan sistematis akan diteliti untuk mengetahui adanya pengaruh dari Penghasilan Bunga, Penghasilan Berpajak Final, Sumbangan Representasi, Denda pajak dan Biaya lain-lain dalam memberikan pengaruhnya terhadap Taxable Income.

\section{Uji Goodness of Fit Test R-Square contribution ratio}

Uji kesesuaian model adalah sebesar kemampuan variable bebas dalam menjelaskan varian variable terkaitnya. Tujuan dilakukannya uji ini untuk mengetahui apakah suatu variable bias didekati menggunakan distribusi atau tidak. Analisis determinasi digunakan untuk mengetahui proporsi keragaman total dalam variabel dependen yang dapat dijelaskan atau diterangkan oleh variablevariabel independen yang ada di dalam model persamaan regresi linier berganda secara bersama-sama. Determinasi atau $\mathrm{R}^{2}$ adalah suatu ukuran untuk mengukur tingkat (keeratan) hubungan linear antara variabel terikat dengan seluruh variabel bebas secara bersama-sama atau mengukur kebaikan suai (goodness of fit) dari persamaan regresi, yaitu memberikan proporsi atau persentase variasi total dalam variabel terikat yang dijelaskan oleh variabel bebas. Analisis ini dapat menginformasikan baik atau buruknya model regresi yang terestimasi, atau dengan kata lain angka tersebut dapat mengukur seberapa dekatkah garis regresi yang terestimasi dengan data sesungguhnya. Nilai koefisien determinasi $\left(\mathrm{R}^{2}\right)$ mencerminkan seberapa besar variasi dari variabel dependen $\mathrm{Y}$ dapat diterangkan oleh variabel independen $X$. Bila nilai koefisien determinasi sama dengan $0\left(\mathrm{R}^{2}=0\right)$, artinya variasi dari $\mathrm{Y}$ 
tidak dapat diterangkan oleh $\mathrm{X}$ sama sekali. Sementara bila $\mathrm{R}^{2}=1$, artinya variasi dari $\mathrm{Y}$ secara keseluruhan dapat diterangkan oleh X. Dengan kata lain bila $\mathrm{R}^{2}=1$, maka semua titik pengamatan berada tepat pada garis regresi, sehingga baik atau buruknya suatu persamaan regresi ditentukan oleh $\mathrm{R}^{2}$ nya yang mempunyai nilai antara nol dan satu. Untuk pengamatan dua variabel (satu variabel terikat dan satu variabel bebas), besaran $\mathrm{r}$ (biasa dituliskan dengan huruf kecil untuk dua variabel) dapat bernilai positif maupun negatif (antara $-1 \mathrm{~s} / \mathrm{d} 1$ ), tetapi untuk lebih dari dua variabel, besaran $\mathrm{R}$ selalu bernilai positif (antara 0 s/d 1). Pengamatan dengan lebih dari dua variabel umumnya menggunakan Adjusted $\mathrm{R}$ square. Menurut Santoso dalam buku (Priyatno, 2008), Adjusted R square adalah $\mathrm{R}$ square yang telah disesuaikan. Nilai Adjusted $\mathrm{R}$ square ini selalu lebih kecil dari $\mathrm{R}$ square dan bisa memiliki harga negatif.

\section{Uji Model Fit Indices and P-Square.}

Uji ini memberikan dua hasil sekaligus yaitu untuk mengambil keputusan apakah $\mathrm{H}_{0}$ ditolak atau diterima, serta memberikan informasi mengenai peluang terjadinya kejadian yang disebut dalam $\mathrm{H}_{0}$. Inerpretasi indicator model fit tergantung dari tujuan analisis SEM. Jika tujuan penelitian hanya menguji hipotesis hubungan antara variable laten maka indicator model fit menjadi kurang penting. Namun jika tujuan penelitian adalah menentukan model yang terbaik dari beberapa model yang berbeda maka indeks fit sangat penting.

\section{Uji Path Coefficients and P-values}

Uji Path Coefficients and P-values digunakan untuk mengetahui estimasi koefisien jalur (path coefficients) dan $p$ value masing-masing variable independen terhadap varibel dependen. Uji ini dilakukan untuk menguji $\mathrm{H}_{1}-\mathrm{H}_{4}$. Adapun langkah-langkah pengujian sebagai yaitu :
Menentukan Hipotesis, Menentukan tingkat kesalahan ( $\alpha$ ), Menginterpretasikan hasil pengujian, Melakukan analisis dan perumusan dan Menyusun kesimpulan berdasarkan integrity hasil uji dan analisanya.

\section{Uji Moderasi dengan SEM Warp-PLS.}

Pengujian hipotesis moderasi dilakukan dengan moderated regression analysis (MRA) yang diestimasi dengan SEM-PLS (Baron dan Kenny, 1986; Bisbe dan Otley, 2004; Kock, 2011). Untuk menguji SPM sebagai variabel pemoderasi hubungan antara inovasi dan kinerja, fokus perhatian adalah pada koefisien interaksi antara inovasi dan SPM. Hipotesis 2 didukung jika koefisien interaksi tersebut bernilai positif dan signifikan. Kuatnya korelasi antara dependen dan independen tergantung dari besarnya error. Semakin besar error, semakin kecil kekuatan korelasi dua variabel. Dalam penelitian ini korelasi terdapat pada kuadran 4, variabel penghasilan bunga, penghasilan berpajak final, dan sumbangan representasi dan beban pajak sebagai variabel moderator tidak berhubungan dengan variabel endogen tetapi berinteraksi dengan variabel eksogen atau secara metematis dapat dituliskan persamaan regresi:

\section{TIit $=\beta 0+\beta 1$ PBit $+\beta 2$ PBFit $+\beta 3$ SRit $+\beta 4$ BPit $+\beta 5$ PB*SRit + $\beta 6$ PBF*BPit + eit}

Dimana :

TIit = Taxable Income perusahaan $\mathrm{i}$ pada periode $\mathrm{t}$.

$\beta 0=$ Konstanta (nilai Tlit apabila PBit, PBF it, PB*SRit + $\beta 4 \mathrm{PBF}^{*} \mathrm{BPit}$ adalah sama dengan $0(\mathrm{Nol})$ ).

$\beta 1=$ Koefisien regresi PBit.

B2 = Koefisien regresi PBFit.

B3 = Koefisien regresi SRit.

$\mathrm{B} 4=$ Koefisien regresi BPit.

$\mathrm{B} 5=$ Koefisien regresi $\mathrm{PB} *$ SRit.

B6 $=$ Koefisien regresi $\mathrm{PBF}^{*}$ BPit.

eit $=$ Faktor-faktor lain diluar variabel penelitian. 
PBit = Penghasilan Bunga perusahaan $\mathrm{i}$ pada periode $t$.

PBFit $=$ Penghasilan Berpajak Final perusahaan i pada periode $t$.

SRit = Sumbangan Representasi perusahaan i pada periode $t$.

BPit = Beban pajak perusahaan i pada periode $t$.

Metode ini digunakan dengan tujuan untuk mengetahui adanya pengaruh dari masingmasing variabel independen terhadap variabel dependen dan sekaligus memprediksi nilai variabel dependen terkait dengan perubahan variabel independen.

\section{HASIL DAN PEMBAHASAN}

\section{Uji Goodness of Fit Test R-Square contribution ratio}

Hasil pengujian kesesuaian model atau Goodness of Fit Test R-Square dalam penelitian ini digunakan untuk mengetahui beberapa persentase variansi konstruksi varibel independen yang menjelaskan pengaruhnya terhadap variable dependen. Semakin tinggi $R$-Square contribution ratio menunjukan model yang baik. Berikut adalah ilustrasi pengujian $R$ Square contribution ratio, yaitu:

Hasil Uji Kesesuaian Nodel (R-square contribution ratio)

\begin{tabular}{|c|c|}
\hline R-squared contributionratio (RSCR) & $=0.886$, acceptable if $>0.9$, ideally $=1$ \\
\hline Statisticalsuppression ratio (SSR) & $=0.667$, acceptable if $>=0.7$ \\
\hline Average adjusted R-squared (AARS) & $=4.249, P<0.001$ \\
\hline
\end{tabular}

Dari dari uji model RSCR pada tabel 4.2 menunjukan hasil yang cukup baik terbukti dari hasil RSCR 0,886 yang mendekati hasil 0,9 , begitu juga dengan hasil SSR yaitu 0,667 yang juga mendekati hasil 0,7, jadi jelas hasil pengujian model ini cukup baik.Pretest ini dilakukan pada 10 responden yang merupakan populasi dan bukan dijadikan sebagai sampel, di dalam kuesioner terdapat 23 butir pernyataan yang harus dijawab responden, dan hasil jawaban kuesioner akan dilakukan pengujian validitas dan pengujian reliabilitas

\section{Uji Model Fit Indices and P-Square.}

Hasil pengujian model fit and P-Value dalam penelitian ini digunakan untuk mengetahui besarnya koefisien dan tingkat signifikan hubungan penghasilan bunga terhadap taxable income, yang bias dilihat sebagai berikut:

\begin{tabular}{|l|} 
Hasil Uji Model Fit Indices \\
\begin{tabular}{|lc|}
\hline Average Path Coefficient $(A P C)$ & $=0.993, P<0.001$ \\
Average R-squared $($ ARS $)$ & $=4.003, P<0.001$ \\
Average blockVIF $($ AVIF $)$ & $=33.282$, acceptable if $<=5$, ideally $<=3.3$ \\
\hline
\end{tabular}
\end{tabular}

Berdasarkan table 4.2 menunjukan kriteria goodness of fit Model telah terpenuhi yaitu dengan nilai APC sebesar 0,993 dan ARS sebesar sebesar 4,003 dengan hasil yang signifikan. Nilai AVIF sebesar 33,282 juga telah memenuhi kriteria. Sehingga dari penjelasan hasil uji ini dapat diambil kesimpulan bahwa model ini sudah memenuhi ketentuan kriteria.

\section{Uji Path Coefficients and P-values}

Hasil pemgujian Path Coefficients and Pvalues dalam penelitian ini digunakan untuk mengetahui hasil estimasi koefisien jalur Path Coefficients dan P-values antara penghasilan bunga, penghasilan berpajak final terhadap taxable income. Adapun hasil anlisis Warp-PLS adalah sebagai berikut:

\begin{tabular}{|c|c|c|}
\hline \multirow{2}{*}{ Path } & \multicolumn{2}{|c|}{ Direct Effect } \\
\cline { 2 - 3 } & B & P-Value \\
\hline \multirow{2}{*}{ PB } & $-0,23$ & 0,02 \\
\hline \multirow{2}{*}{ PBF } & 0,61 & $<0,01$ \\
\hline \multirow{2}{*}{ Path } & \multicolumn{2}{|c|}{ Moderating Effect } \\
\cline { 2 - 3 } & Koefisien & P-Value \\
\hline \multirow{2}{*}{ PB*SR } & $-0,17$ & 0,05 \\
\hline PBF*BP & $-1,52$ & $<0,01$ \\
\hline
\end{tabular}

Berdasarkan output dari Warp-PLS adalah varibel yang telah distandarisasikan sehingga dapat diinterpretasikan yaitu, satu koefisien penghasilan bunga terhadap taxable income sebesar $-0,23$, juga satu koefisien penghasilan berpajak final terhadap taxable income sebesar 0,61 , juga 
satu koefisien penghasilan bunga terhadap taxable income yang dimoderasi oleh sumbangan representasi sebesar -0,17 dan satu koefisien penghasilan berpajak final terhadap taxable income yang dimoderasi oleh beban pajak sebesar $-0,17$.

\section{Uji Moderasi dengan Warp-PLS}

Hasil Penelitian ini dibantu dengan menggunakan bantuan software Warp-PLS 6.0, untuk mengetahui hubungan antara variable Independen dengan variable dependen. Adapun hasil pengujian WarpPLS sebagai berikut:

\begin{tabular}{|c|c|c|c|}
\hline \multirow{2}{*}{ Path } & \multicolumn{3}{|c|}{ Direct Effect } \\
\cline { 2 - 4 } & B & $\begin{array}{c}\text { P- } \\
\text { Value }\end{array}$ & Kesimpulan \\
\hline \multirow{2}{*}{ PB } & $-0,23$ & 0,02 & Signifikan \\
\hline PBF & 0,61 & $<0,01$ & Signifikan \\
\hline SR & $-0,16$ & 0,06 & Signifikan \\
\hline BP & 3,27 & $<0,01$ & Signifikan \\
\hline \multirow{3}{*}{ Path } & \multicolumn{3}{|c|}{ Moderating Effect } \\
\cline { 2 - 4 } & Koefisien & $\begin{array}{c}\text { P- } \\
\text { Value }\end{array}$ & Kesimpulan \\
\hline \multirow{2}{*}{ PB*SR } & $-0,17$ & 0,05 & Moderasi Semu \\
\hline PBF*BP & $-1,52$ & $<0,01$ & Moderasi Semu \\
\hline
\end{tabular}

Berdasarkan hasil rangkuman table koefisien diatas dapat dijelaskan bahwa penghasilan bunga memiliki nilai koefisien $-0,23$ dan memiliki nilai P-Value sebesar 0,02 , yang artinya dapat simpulakan bahwa memiliki pengaruh yang sangat erat atau signifikan. Pada kolom berikutnya juga dapat dijelaskan bahwa penghasilan berpajak final memiliki nilai koefisien 0,61 dan memiliki nilai P-Value sebesar $<0,01$ yang artinya dapat simpulakan bahwa memiliki pengaruh yang sangat erat atau signifikan. Pada kolem ke lima digambarkan hasil pengaruh moderasi yang dijelaskan bahwa penghasilan bunga berpagaruh signifikan terhadap taxable income dengan terlebih dahulu dimoderasi oleh sumbangan representasi dengan nilai koefesien -0,17 dan nilai P-Value senilai 0,05 yang menunjukan ada pengaruh yang signifikan terhadap taxable income artinya hasil ini menunjukan terdapat moderasi semu. Terjadi hasil yang sama pada kolem ke enam digambarkan hasil pengaruh moderasi yang dijelaskan bahwa penghasilan berpajak final berpagaruh signifikan terhadap taxable income dengan terlebih dahulu dimoderasi oleh beban pajak dengan nilai koefesien -1,52 dan nilai P-Value senilai $<0,01$ yang menunjukan ada pengaruh yang signifikan terhadap taxable income artinya hasil ini menunjukan terdapat moderasi semu. Berdasarkan hasil rangkuman table koefisien diatas dapat dijelaskan bahwa semua variable independen sangat berpagaruh terhadap taxable income yang artinya dapat simpulakan bahwa memiliki pengaruh yang sangat erat atau signifikan, begitu pula pada hasil moderating effect keduanya menujukan hasil yang berparuh signifikan yang menghasilkan moderasi semu.

\section{Pembahasan}

Dalam pembahasan hasil penelitian ini, diuraikan masing-masing variabel yang terkait, yaitu pembahasan tentang hasil uji hipotesis terkait dengan pengaruh penghasilan bunga terhadap taxable income, pengaruh penghasilan berpajak final terhadap taxable income, pengaruh penghasilan bunga terhadap taxable income yang dimoderasi oleh sumbangan representasi, dan pengaruh penghasilan berpajak final terhadap taxable income yang dimoderasi oleh beban pajak. Yang diuraikan sebagai berikut:

\section{Pengaruh Penghasilan Bungan Terhadap Taxabel Income}

Dalam pengujian ini peneliti menemukan adanya perbedaan perhitungan menurut SAK maupun peraturan perpajakan disebabkan penggunaan metode dan ketentuan yang berlaku. Misalnya dalam hal penentuan pendapatan Bunga dimana bunga tersebut pada dasarnya sudah dikenalkan pajak terlebih dahulu ketika dikelola oleh perbankan. Namun untuk keperluan perpajakan perusahaan harus mengikuti Peraturan Menteri Keuangan Nomor 26/PMK.10/2016 tentang 
pemotongan pajak penghasilan atas bunga deposito dan tabungan serta diskonto sertifikat bank Indonesia. Perbedaan perhitungan Penghasilan Bunga, dimana penghasilan bunga menurut metode akuntansi yang berlaku umum menunjukkan nilai yang lebih tinggi dibandingkan penghasilan bunga menurut peraturan pajak, maka ditemukan adanya koreksi fiskal positif yang mengakibatkan adanya pengurangan biaya yang telah diakui dalam laporan laba-rugi komersial yang pada akhirnya akan menurunkan biaya dan tentunya berdampak pada peningkatan Taxabel Income. Sebaliknya perbedaan perhitungan Penghasilan Bunga, dimana penghasilan bunga menurut SAK menunjukkan nilai yang lebih rendah dibandingkan penghasilan bunga menurut ketetapan dalam undangundang perpajakan, maka ditemukan adanya koreksi fiskal negatif yang mengakibatkan adanya penambahan biaya yang telah diakui dalam laporan laba-rugi komersial yang pada akhirnya akan meningkatkan biaya dan tentunya berdampak pada penurunan Taxabel Income. Dari hasil pengujian yang telah dilaksanakan pada uraian sebelumnya, telah membuktikan bahwa Penghasilan Bunga berpengaruh secara signifikan terhadap Taxabel Income. Itu dibuktikan dengan semakin besarnya pendapatan bunga maka semakin menurunnya taxable income. Ini jelas sangat merugikan penyelenggara usaha apabila tidak dilakukan koreksi fiscal. Dari hasil pengujian ini juga dapat disimpulkan bahwa hasilnya sesuai dengan hasil pengujian sebelumnya yaitu Riyana (2015) yang berpengaruh signifikan terhadap taxable income.

\section{Pengaruh Penghasilan Berpajak Final Terhadap Taxabel Income}

Dalam pengujian ini peneliti menemukan adanya perbedaan perhitungan menurut SAK maupun peraturan perpajakan disebabkan penggunaan metode dan ketentuan yang berlaku. Misalnya dalam hal penentuan pendapatan berpajak final dimana bunga tersebut pada dasarnya sudah dikenalkan pajak terlebih dahulu ketika dikelola oleh Pihak pertama. Namun untuk keperluan perpajakan perusahaan harus mengikuti Peraturan Menteri Keuangan Nomor 26/PMK.10/2016 tentang pemotongan pajak penghasilan atas bunga deposito dan tabungan serta diskonto sertifikat bank Indonesia. Pajak Penghasilan Final (PPh Final) adalah pajak yang dikenakan dengan tarif dan dasar pengenaan pajak tertentu atas penghasilan yang diterima atau diperoleh selama tahun berjalan. Pembayaran, pemotongan atau pemungutan Pajak Penghasilan Final (PPh Final) yang dipotong pihak lain maupun yang disetor sendiri bukan merupakan pembayaran dimuka atas $\mathrm{PPh}$ terutang akan tetapi merupakan pelunasan $\mathrm{PPh}$ terutang atas penghasilan tersebut, sehingga wajib pajak dianggap telah melakukan pelunasan kewajiban pajaknya. Pengenaan PPh secara final mengandung arti bahwa atas penghasilan yang diterima atau diperoleh akan dikenakan $\mathrm{PPh}$ dengan tarif tertentu dan dasar pengenaan pajak tertentu pada saat penghasilan tersebut diterima atau diperoleh. PPh yang dikenakan, baik yang dipotong fihak lain maupun yang disetor sendiri, bukan merupakan pembayaran di muka atas $\mathrm{PPh}$ terutang tetapi sudah langsung melunasi $\mathrm{PPh}$ terutang untuk penghasilan tersebut. Dengan demikian, penghasilan yang dikenakan $\mathrm{PPh}$ final ini tidak akan dihitung lagi $\mathrm{PPh}$ nya di SPT Tahunan untuk dikenakan tarif umum bersamasama dengan penghasilan lainnya. Begitu juga, PPh yang sudah dipotong atau dibayar tersebut juga bukan merupakan kredit pajak di SPT Tahunan. Berdasarkan Pasal 4 ayat (2) Undang-undang Pajak Penghasilan, Undang-undang memberikan mandat kepada Pemerintah untuk mengenakan $\mathrm{PPh}$ final atas penghasilanpenghasilan tertentu. Berdasarkan ketentuan ini Pemerintah mengeluarkan Peraturan Pemerintah untuk mengenakan 
PPh final atas penghasilan tertentu dengan pertimbangan kesederhanaan, kemudahan, serta pengawasan.Pengenaan $\mathrm{PPh}$ Final sebagian berasal dari ketentuan Pasal 4 ayat (2) ini. Namun demikian, ada juga pengenaan $\mathrm{PPh}$ final berdasarkan Pasal lain yaitu Pasal 15, Pasal 19, Pasal 21, Pasal 22, Pasal 23 dan Pasal 26 Undangundang $\mathrm{PPh}$. Dengan demikian maka penghasilan yang telah dikenakan Pajak Penghasilan Final ( $\mathrm{PPh}$ final) ini tidak akan dihitung lagi Pajak Penghasilannya pada SPT Tahunan dengan penghasilan lain yang non final untuk dikenakan tarif progresssif (pasal $17 \mathrm{UU} \mathrm{PPh}$ ). Namun atas pelunasan pemotongan atau pembayaran $\mathrm{PPh}$ final tersebut juga bukan merupakan kredit pajak pada SPT Tahunan. Dari gambaran penjelasan diatas jelas ketika penghasilan berpajak final dikenakan pajak kembali maka akan merugikan pelaku usaha atau emiten, jadi jelas semakin tinggi penghasilan bepajak final, maka akan semakin besar pula taxable income, sesuai dengan hasil pengujian yang dilakukan oleh peneliti. Dari hasil pengujian ini juga dapat disimpulkan bahwa hasilnya sesuai dengan hasil pengujian sebelumnya yaitu Julioe (2017) yang berpengaruh signifikan terhadap taxable income.

\section{Pengaruh Penghasilan Bungan Terhadap Taxabel Income Dimoderasi Sumbangan Representasi}

Pada bagian ini peneliti membahas tentang perbedaan perhitungan Penghasilan Bunga, dimana penghasilan bunga menurut metode akuntansi yang berlaku umum menunjukkan nilai yang lebih tinggi dibandingkan penghasilan bunga menurut peraturan pajak, maka ditemukan adanya koreksi fiskal positif yang mengakibatkan adanya pengurangan biaya yang telah diakui dalam laporan laba-rugi komersial yang pada akhirnya akan menurunkan biaya dan tentunya berdampak pada peningkatan Taxabel Income. Sebaliknya perbedaan perhitungan Penghasilan Bunga, dimana penghasilan bunga menurut SAK menunjukkan nilai yang lebih rendah dibandingkan penghasilan bunga menurut ketetapan dalam undangundang perpajakan, maka ditemukan adanya koreksi fiskal negatif yang mengakibatkan adanya penambahan biaya yang telah diakui dalam laporan laba-rugi komersial yang pada akhirnya akan meningkatkan biaya dan tentunya berdampak pada penurunan Taxabel Income. Dari penjelasan diatas jelas penghasilan bunga mempengaruhi penurunan taxable income terlebih lagi apabila dimoderasi oleh sumbangan representasi, ini sesuai dengan hasil pengujian yang telah dilakukan oleh peneliti bahwasanya penghasilan bunga meningkat maka taxable income akan menurun sesuai dengan ketuntuan SAK begitu juga sebaliknya, juga apabila dipengaruhi oleh sumbangan representasi. Dari hasil pengujian ini juga dapat disimpulkan bahwa hasilnya sesuai dengan hasil pengujian sebelumnya yaitu Annisa (2017) yang berpengaruh signifikan terhadap taxable income.

\section{Pengaruh Penghasilan Berpajak Final Terhadap Taxabel Income Dimoderasi Beban Pajak.}

Pada bagian terakhir ini peneliti membahas tentang perbedaan perhitungan Penghasilan Berpajak final, dimana penghasilan berpajak final menurut metode akuntansi yang berlaku umum menunjukkan nilai yang lebih tinggi dibandingkan penghasilan bunga menurut peraturan pajak, maka ditemukan adanya koreksi fiskal positif yang mengakibatkan adanya pengurangan biaya yang telah diakui dalam laporan laba-rugi komersial yang pada akhirnya akan menurunkan biaya dan tentunya berdampak pada peningkatan Taxabel Income. Sebaliknya perbedaan perhitungan penghasilan berpajak final, dimana penghasilan berpajak final menurut SAK menunjukkan nilai yang lebih rendah dibandingkan penghasilan bunga menurut ketetapan dalam undang-undang perpajakan, maka 
ditemukan adanya koreksi fiskal negatif yang mengakibatkan adanya penambahan biaya yang telah diakui dalam laporan laba-rugi komersial yang pada akhirnya akan meningkatkan biaya dan tentunya berdampak pada penurunan Taxabel Income. Dari penjelasan diatas jelas penghasilan berpajak final mempengaruhi penurunan taxable income. Namun apabila beban pajak ikut menjadi komponen yang ada dalam penghasilan berpajak final justru beban pajak akan ikut melemahkan pengaruhnya terhadap taxable income, yang telah dilakukan oleh peneliti bahwasanya penghasilan berpajak finil meningkat maka taxable income akan menurun sesuai dengan ketentuan SAK begitu juga sebaliknya, juga apabila dipengaruhi oleh beban pajak. Dari hasil pengujian ini juga dapat disimpulkan bahwa hasilnya sesuai dengan hasil pengujian sebelumnya yaitu Brolin (2014) yang berpengaruh signifikan terhadap taxable income.

\section{KESIMPULAN DAN SARAN}

\section{Kesimpulan}

Pada akhir penelitian ini peneliti mengambil kesimpulan dari Tujuan penelitian ini adalah mengidentifikasi pengaruh penghasilan bunga terhadap taxable income, pengaruh penghasilan berpajak final terhadap taxable income, pengaruh penghasilan bunga terhadap taxable income yang dimoderasi oleh sumbangan representasi, dan pengaruh penghasilan berpajak final terhadap taxable income yang dimoderasi oleh beban pajak pada 16 perusahan manufaktur untuk sub sector logam dan sejenisnya, yang terdaftar di Bursa Efek Indonesia dalam kurun waktu dari tahun 2013-2017, dengan total sampel sebanyak 80 item. Model desain yang digunakan dalam melakukan penelitian ini adalah riset kuantitatif (hypo tchco-deductive), yaitu penelitian yang dilakukan untuk menguji hipotesis, metode yang digunakan dalam penelitian ini adalah kuantitatif dengan menggunakan data statistic yang akan diolah dengan menggunakan Structural Equation Modeling-Partial Least Squares (SEM-PLS) versi WarpPLS. Penelitian ini menunjukan hasil yang dapat disimpulkan Penghasilan bunga memiliki pengaruh yang signifikan terhadap taxable income. Hal ini mengindikasikan bahwa perbedaan persentase di dalam menghitung pengenaan pajak penghasilan bunga antara ketentuan dalam perpajakan dan menurut standard akuntansi yang berlaku sangat menentukan didalam perolehan hasil perhitungan taxabel income, juga penghasilan berpajak final memiliki pengaruh yang signifikan terhadap taxable Income. Hal ini mengindikasikan bahwa perbedaan persentase di dalam menghitung pengenaan pajak penghasilan berpajak final antara ketentuan dalam perpajakan dan menurut standard akuntansi yang berlaku sangat menentukan didalam perolehan hasil perhitungan taxabel income, juga penghasilan bunga yang dimoderasi oleh sumbangan representasi menunjukkan adanya pengaruh sinifikan terhadap taxabel income. Hal ini mengindikasikan bahwa moderasi oleh variabel sumbangan representasi justru menambah pengaruh penghasilan bunga terhadap taxabel income. Dengan demikian maka bisa disimpulkan bahwa antara variabel penghasilan bunga dan variabel sumbangan representasi memiliki posisi yang sama-sama mempengaruhi terhadap taxabel income dan penghasilan berpajak final yang dimoderasi oleh Beban Pajak menunjukkan adanya pengaruh yang signifikan terhadap taxabel income. Hal ini mengindikasikan bahwa moderasi oleh variabel beban pajak adalah mendukung pengaruh penghasilan berpajak final terhadap taxabel income.

\section{Saran}

Pada penelitian selanjutnya disarankan untuk mengembangkan penelitian lebih lanjut dengan penambahan variabelvariabel lain yang mempengaruhi Taxabel 
Incom, memperluas sample perusahaan, tidak hanya perusahaan manufaktur di sub sektor logam saja, memperluas tahun penelitian lebih dari lima tahun serta menambahkan variable yang saling memoderasi moderasi disemua variable. Saran untuk pemerintah yaitu diperlukan adanya peraturan dan regulasi perpajakan yang jelas dan spesifik, dan mempertimbangkan adanya modernisasi sistem administrasi pada perpajakan untuk transaksi taxabel income.

\section{DAFTAR PUSTAKA}

Kasmir, 2012. Bank dan Lembaga Kuangan Lainnya. Jakarta : PT. Raja Grafindo. Persada. Hasibuan.

Agoes, dkk., 2010. Akuntansi Perpajakan, Edisi 2, Revisi, Jakarta : Salemba empat.

Pallant, 2008. A step by step guide to data analysis using SPSS for Windows (Version 10).

Suandy, 2008. Perencanaan Pajak. Salemba Empat : Jakarta.

Harnanto, 2008. Akuntansi Perpajakan, BPFE, Jogjakarta

Donald E. Kieso, dkk., 2008. Akuntansi Intermediate, Edisi ke Dua Belas, Jilid 1, Jakarta : Erlangga.

Chorvat T, 2007. Tax Compliance and the Neuroeconomics of Intertemporal Substitution.

John. C. Shaw, 2003. Corporate Governance and Risk : A System Approach, John Wiley \& Sons, Inc, New Jersey.

Arikunto, dkk., 2002. Prosedur Penelitian Suatu Pendekatan dan Praktek. Jakarta : Rineka Cipta.

Tjahyono, dkk., 2000. Perpajakan. Yogyakarta : Akademi Perusahaan YKPN.

Bathala, et all., 1994. Managerial Ownership, Debt Policy, and The Impact of Institutional Holdings : An Agency Perspectiveî. Financial Management. Vol. 23, hal. 38.Andreoni, et all., 1998. Tax Compliance, Vol. 1.
Gaspersz, V., 1991. Metode Perancangan Percobaan, CV .ARMICO. Bandung

Absari, D. U. A., Sudarma, M., \& Chandrarin, G. (2013). Analisis Pengaruh Faktor Fundamental Perusahaan Dan Risiko Sistematis Terhadap Return Saham. El Muhasaba: Jurnal Akuntansi, 3(2).

Anwar, M. (2016). Impact of Firms Performance on Stock Returns (Evidence from Listed Companies of FTSE-100 Index London, UK). Global Journal of Management And Business Research, 16(1).

Supand,dkk (2016). Pengaruh faktor fundamental dan risiko sistematis terhadap return saham syariah. Media Riset Akuntansi, Auditing dan Informasi, 2016, 12.1: 23-24.

Arindia, C. A., Handayani, S. R., \& Rahayu, S. M. (2013). Analisis Rasio Keuangan dan Metode Economic Value Added (Eva) sebagai Penilaian Kinerja Keuangan Perusahaan (Studi Pada Perusahaan Cement yang Termasuk Dalam Saham Blue Chip yang Terdaftar Di Bursa Efek Indonesia Periode 2009-2011). Jurnal Administrasi Bisnis, 2(2), 208-116.

Asmi, T. L. (2014). Current Ratio, Debt To Equity Ratio, Total Asset Turnover, Return On Asset, Price To Book Value Sebagai Faktor Penentu Return Saham. Management Analysis Journal, 3(2).

Budialim, G. (2013). Pengaruh Kinerja Keuangan dan Risiko Terhadap Return Saham Perusahaan Sektor Consumer Goods Di Bursa Efek Indonesia Periode 2007-2011. Jurnal Ilmiah Mahasiswa Universitas Surabaya, 2(1), 28.

Dwi Putra, I., \& Dana, I. Pengaruh Profitabilitas, Leverage, Liquiditas Dan Ukuran Perusahaan Terhadap Rreturn Saham Perusahaan Farmasi di BEI. E-Jurnal Manajemen Universitas Udayana, 5(11). 